\title{
PERAN KEPALA SEKOLAH DAN PUSTAKAWAN DALAM PEMBERDAYAAN PERPUSTAKAAN SD MUHAMMADIYAH SAPEN DAN SD NEGERI GIWANGAN
}

\author{
Widya Setyaningrum Bagyoastuti, Wiwik Wijayanti \\ Sekolah Pelita Harapan Sentul City Bogor, FIP Universitas Negeri Yogyakarta \\ widya_bagyoastuti@yahoo.com; wiwikashari@gmail.com
}

\begin{abstract}
Abstrak
Penelitian ini bertujuan untuk mendeskripsikan: (1) peran kepala sekolah dan (2) peran pustakawan dalam memberdayakan perpustakaan sekolah dasar, serta (3) upaya pemberdayaan perpustakaan sekolah dasar. Pendekatan kualitatif digunakan dalam penelitian ini dengan menjadikan perpustakaan SD Muhammadiyah Sapen dan SD Negeri Giwangan sebagai subjek penelitian. Data penelitian dikumpulkan melalui teknik observasi, wawancara, dan dokumentasi kemudian dianalisis dengan mengacu pada model interaktif menurut Miles dan Huberman. Hasil penelitian menunjukkan bahwa pemberdayaan perpustakaan sekolah dasar dimulai manakala terdapat dukungan kepala sekolah dan hadirnya pustakawan penuh waktu yang profesional. Kepala sekolah berperan sebagai (1) manajer sekolah, (2) pemimpin instruksional, dan (3) agen perubahan. Pustakawan berperan sebagai (1) manajer perpustakaan, (2) ahli informasi dan penggiat literasi informasi, (3) pelaku instruksional, dan (4) kolaborator. Pemberdayaan perpustakaan diarahkan pada tigas aspek, yaitu (1) peningkatan kolaborasi antara pustakawan dengan guru, (2) pengembangan keterampilan literasi informasi yang terintegrasi ke dalam pembelajaran, dan (3) peningkatan partisipasi warga sekolah terhadap pengembangan koleksi pustaka.

Kata kunci: peran kepala sekolah, peran pustakawan, pemberdayaan perpustakaan sekolah.
\end{abstract}

\section{ROLES OF SCHOOL PRINCIPAL AND LIBRARIAN IN EMPOWERING ELEMENTARY SCHOOL LIBRARY OF MUHAMMADIYAH ELEMENTARY SCHOOL OF SAPEN AND GIWANGAN ELEMENTARY PUBLIC SCHOOL}

\author{
Widya Setyaningrum Bagyoastuti, Wiwik Wijayanti \\ Sekolah Pelita Harapan Sentul City Bogor, FIP Universitas Negeri Yogyakarta \\ widya_bagyoastuti@yahoo.com; wiwikashari@gmail.com
}

\begin{abstract}
This study aims to describe the roles of principal as well as librarian in empowering elementary school library, and efforts in empowering elementary school library. This research used qualitative approach and involved two elementary school libraries as subject research; they were library of Muhammadiyah Elementary School of Sapen and Giwangan Elementary Public School. The data were collected through observation, interview, and documentations and analysed using interactive analysis of Miles and Huberman. The results of this study show that an elementary school libraries start to be useful when they have principal support and a fulltime credentialed librarian. The school principals play important roles as (1) the school manager, (2) instructional leader, and (3) agent of change. The school librarians also conduct four different roles as (1) the library manager, (2) information specialist and information literacy instructor, (3) instructional partner, and (4) collaborator. Elementary school library empowerment should be directed to (1) enhance collaboration between librarian and teachers in instructional area, (2) develop information literacy skills which is integrated on instructional basis, and (3) increase library users' participation in improving library's collections.
\end{abstract}

Keywords: roles of school principal, roles of librarian, elementary school library empowerment. 


\section{Pendahuluan}

Sebuah penyelenggara pendidikan seyogyanya senantiasa berupaya menyediakan lingkungan pembelajaran yang efektif bagi seluruh peserta didik dan salah satu faktor pendukungnya adalah ketersediaan pustaka yang dapat mendukung proses pembelajaran sekaligus memenuhi beragam kebutuhan para penggunanya. Sekolah sebagai salah satu penyelenggara pendidikan wajib menyediakan pustaka yang dibutuhkan oleh warga sekolah.

Berdasarkan data dan informasi dari Dinas Dikpora DIY tahun 2013, terdapat 1.851 sekolah dasar yang terdiri dari 1.460 sekolah negeri dan 391 sekolah swasta di seluruh kabupaten dan kota Daerah Istimewa Yogyakarta. Semua sekolah tersebut diakui telah mempunyai perpustakaan meskipun tidak tersedia informasi detil mengenai kondisinya.

Sebagai salah satu komponen Standar Sarana dan Prasaran Pendidikan, perpustakaan tidak luput dari aspek manajemen pendidikan. Dalam artikelnya, Darmono (2007) mengemukakan bahwa perpustakaan berperan penting sebagai sumber belajar dan salah satu komponen instruksional. Selain itu, perpustakaan juga merupakan sumber penunjang kualitas pendidikan dan pengajaran, dan sebagai laboratorium belajar yang memungkinkan peserta didik mempertajam dan memperluas kemampuan membaca, menulis, berpikir, dan berkomunikasi.

Perubahan pola belajar masyarakat masa kini turut mendorong perlunya perubahan pola pembelajaran di sekolah. Tilaar (1998, p. 176) menjelaskan bahwa dalam era informasi seperti saat ini, cara belajar-mengajar indoktriner dan menghafal menjadi tidak relevan lagi. Yang perlu dikuasai oleh peserta didik adalah mengolah sendiri informasi yang diperoleh atau belajar mandiri. Mereka harus dapat mencari sendiri informasi yang diperlukan, dengan tuntunan guru bila diperlukan. Proses belajar mandiri dapat berlangsung apabila ditopang dengan fasilitas dan sumber belajar yang memadai seperti perpustakaan yang lengkap.
Menurut Edwards dan Fisher (2002, pp. 21-22), perpustakaan sekolah tergolong ke dalam perpustakaan akademik karena seluruh koleksi pustaka yang dimiliki ditujukan untuk mendukung kegiatan akademik ataupun penelitian. Perpustakaan akademik mempunyai ciri-ciri: (a) menekankan pada tujuan untuk mendukung pembelajaran, (b) memiliki koleksi yang mendukung penelitian, (c) koleksi jurnal yang beragam, (d) jaringan komputer dan elektronik yang mendukung, dan (e) jaringan internal luas dan mencakup seluruh unit kerja.

Parr (2012, pp. 18-22) merumuskan tiga peran penting perpustakaan di sekolah. Pertama, sebagai agen katalisator untuk pertukaran informasi dan pengembangan intelektual siswa. Kedua, perpustakaan menawarkan program pembinaan minat baca yang kolaboratif dan memberikan motivasi kepada pemustaka. Ketiga, berperan dalam memilih dan memilah sumber-sumber, baik cetak maupun non cetak, yang dapat digunakan untuk mendukung kebutuhan pembelajaran.

Perubahan konstruktif dalam model pembelajaran tersebut harus dapat disikapi oleh perpustakaan. Keberadaan perpustakaan sekolah tidak akan berpengaruh nyata apabila hanya digunakan sebagai ruangan penyimpanan buku yang pasif menerima kunjungan pengguna saja. Sebagai growing organism, perpustakaan perlu dikelola secara dinamis mengikuti perkembangan dunia pendidikan dengan menciptakan lingkungan pembelajaran yang optimal dan memberikan fleksibilitas, ruang gerak yang memadai, multiguna dan multifungsi (Prostano dan Prostano, 1977, p. 2; Moore, 1999, p. 22)

Kualitas sarana dan prasarana merupakan simbol kualitas pendidikan yang disediakan sekolah karena dapat mencerminkan kurikulum yang berlaku. Oleh karena itu, sarana dan prasarana sekolah, termasuk perpustakaan, menjadi tanggung jawab kepala sekolah (Barnawi dan Arifin, 2012, p. 82).

Dengan diberlakukannya desentralisasi pendidikan, sekolah memiliki wewe- 
nang yang lebih luas untuk mengelola seluruh komponen pendidikan di lingkungan internal sekolah. Salah satu tugas pokok dan fungsi kepala sekolah adalah mengelola seluruh sarana dan prasarana pendidikan, tanpa terkecuali perpustakaan. Pengelolaan tersebut bertujuan agar sarana dan prasarana, termasuk perpustakaan sekolah dasar, dapat menyediakan lingkungan pembelajaran yang kondusif peserta didik dan mendorong pertumbuhan profesional para guru dan tenaga kependidikan lainnya. Berdasarkan tugas pokok dan fungsi tersebut, kepala sekolah harus berperan aktif untuk memberdayakan perpustakaannya. Meskipun berbagai literatur telah menyatakan pentingnya peran kepala sekolah dalam mengembangkan dan memberdayakan perpustakaan, namun peran tersebut belum nampak di lapangan.

Menurut Kowalski (2010, pp. 10-12), kepala sekolah berperan sebagai manajer, pemimpin, dan administrator. Selaras dengan Kowalski, Cunningham dan Cordeiro $(2009$, p. 144) mengemukakan bahwa peran kepala sekolah mencakup (a) mendefinisikan dan mengkomunikasikan tujuan pendidikan sekolah, (b) mengkoordinasikan kurikulum, (c) melakukan supervisi dan mendukung guru, (d) memantau kemajuan siswa, dan (e) mengembangkan lingkungan pembelajaran yang positif. Whitehead, dkk (2013, p. 8) berpendapat bahwa peran kepala sekolah berkembang dinamis. Semenjak tahun 2000-an hingga saat ini, kepala sekolah tidak hanya sebagai penanggung jawab akuntabilitas tetapi juga pemimpin pembelajaran global, instruksional, teknologi, sosiologis, kolaboratif, multikultural, kesejahteraan, dan lain sebagainya. Selain sebagai manajer dan pemimpin instruksional, Gorton (1976, p. 65-69) juga menyebutkan bahwa kepala sekolah juga berperan sebagai agen perubahan. Pendapat Gorton tersebut selaras dengan peran kepala sekolah yang disampaikan oleh Sergiovanni (2001, p. 49) bahwa kepala sekolah tidak hanya berperan sebagai manajer tetapi juga sebagai motivator, pengembang, dan pembangun komunitas.
Mengacu kepada berbagai teori tersebut, terlihat bahwa kepala sekolah mempunyai andil besar terhadap pemberdayaan perpustakaan sekolah dasar. Kepala sekolah memiliki peran penting sebagai (a) manajer; sebagai manajer, kepala sekolah mengelola, mengorganisasikan, dan mengkoordinasikan seluruh sumber daya materiil maupun nonmateriil yang dimiliki sekolah untuk mencapai tujuan pendidikan yang telah ditetapkan; (b) pemimpin instruksional; sebagai pemimpin instruksional, kepala sekolah berperan penting dalam meningkatkan kualitas pembelajaran yang berlangsung di sekolah melalui perluasan kesempatan untuk kolaborasi antarseluruh komponen internal dan eksternal sekolah dan menumbuhkembangkan lingkungan pembelajaran yang positif; dan (c) agen perubahan; sebagai agen perubahan, kepala sekolah diharapkan mampu mendeteksi perubahan, merumuskan dan mengimplementasikan rencana perubahan yang diperlukan, serta membawa seluruh komponen sekolah siap menghadapi perubahan tersebut.

Kepala sekolah yang berkomitmen untuk memberdayakan perpustakaan sekolah tercermin dengan adanya pustakawan. Menurut Undang-Undang No. 43 Tahun 2007 tentang Perpustakaan, pustakawan adalah seseorang yang memiliki kompetensi yang diperoleh melalui pendidikan dan/atau pelatihan kepustakawanan serta mempunyai tugas dan tanggung jawab untuk melaksanakan pengelolaan dan pelayanan perpustakaan. Pustakawan dapat berasal dari guru yang memperoleh pelatihan kepustakawanan maupun dari ahli perpustakaan.

Menurut International Federation of Library Associations and Institutions (IFLA), pustakawan berperan: (1) mengembangkan dan melaksanakan misi dan tujuan perpustakaan sekolah yang sejalan dengan misi dan tujuan sekolah, (2) aktif dalam pengembangan rencana dan implementasi kurikulum, (3) memiliki pengetahuan dan keterampilan yang berkaitan dengan penyediaan informasi dan pemecahan masalah informasi serta keahlian dalam meng- 
gunakan berbagai sumber, baik cetak maupun elektronik, (4) mengkampanyekan membaca dan promosi bacaan anak, media, dan budaya, (5) menciptakan suasana yang sesuai untuk hiburan dan pembelajaran yang bersifat menarik, ramah, dan terbuka bagi siapa saja tanpa rasa takut dan curiga.

Pada umumnya warga sekolah mengetahui bahwa pustakawan bertanggung jawab untuk mengelola perpustakaan dengan baik sehingga koleksi pustaka yang dimiliki siap dipergunakan oleh pemustaka. Akan tetapi tidak banyak warga sekolah yang memahami bahwa pustakawan juga seorang pemimpin yang proaktif dalam memberikan layanan kepada warga sekolah (Morris, 2010, pp. 30-31).

Istilah proaktif yang digunakan mempunyai makna bahwa: (1) pustakawan mampu mengantisipasi layanan sebelum layanan tersebut dibutuhkan dan mempromosikan layanan tersebut kepada pemustaka. Hal ini menyiratkan bahwa program perpustakaan sangatlah dinamis, aktif dan agresif dalam peningkatan kualitas pembelajaran; (2) bekerja sama dengan guru untuk menyediakan program perpustakaan yang terbaik bagi siswa dan sekolah. Pustakawan dapat menjadi mitra pembelajaran bagi para guru dan menjadi perantara yang membantu para guru untuk mengkoneksikan antara pembelajaran berbasis inquiry dengan keterampilan literasi informasi bagi seluruh level kelas; (3) mampu menjangkau seluruh anggota komunitas sekolah, baik di dalam maupun di luar sekolah, guna mempromosikan layanan perpustakaan dan mewujudkan partisipasi aktif dari seluruh anggota komunitas sekolah.

Peran tersebut dapat terwujud apabila pustakawan mempunyai kompetensi sebagaimana disebutkan dalam Permendiknas No. 25 tahun tentang Standar Tenaga Perpustakaan. Keenam kompetensi tersebut, yaitu kompetensi manajerial, pengelolaan informasi, kependidikan, kepribadian, sosial, dan pengembangan profesi. Keenam kompetensi tersebut membentuk seorang pustakawan bukan hanya sebagai tenaga kependidikan administratif, tetapi juga sebagai profesional kependidikan yang mampu memberdayakan perpustakaan yang dikelolanya.

Penyelenggaraan perpustakaan sekolah didasarkan atas asas pembelajaran sepanjang hayat yang bertujuan untuk memberikan layanan kepada pemustaka dan memperluas wawasan serta pengetahuan untuk mencerdaskan kehidupan bangsa. Sebagai bagian integral dari komunitas sekolah, perpustakaan harus berperan aktif dalam memberikan layanan, bukan hanya sekedar menunggu. Untuk itu, perpustakaan dapat menyusun berbagai program pemberdayaan dan layanan bagi pemustakanya.

Berbagai program atau kegiatan yang dilaksanakan oleh perpustakaan diharapkan dapat memberikan kontribusi positif terhadap proses pendidikan di sekolah. Agar perpustakaan dapat memberikan kontribusi terhadap proses pembelajaran di sekolah, Hughes (1972, pp. 29-38) memaparkan empat aspek yang harus dipertimbangkan ketika menyusun program atau kegiatan. Keempat aspek tersebut ialah (1) ketersediaan, (2) keberagaman, (3) tanggung jawab dan partisipasi, dan (4) motivasi.

Aspek ketersediaan mengacu pada tersedianya beragam pilihan bentuk dan konteks informasi, dan metode untuk mengelola seluruh informasi tersebut serta pendampingan untuk mengevaluasi informasi yang diperoleh. Aspek keberagaman mengacu pada keberagaman koleksi, pengguna, dan model belajar. Diversifikasi bahan pustaka baik dari segi konteks maupun bentuk akan membuat pemustaka terbiasa dengan berbagai bentuk penyimpanan dan komunikasi informasi. Keberagaman pengguna maksudnya pemustaka bebas memanfaatkan perpustakaan secara individu maupun berkelompok. Dengan beragamnya pengguna maka dengan sendirinya model belajar pemustaka pun beragam. Keberagaman inilah yang perlu difasilitasi oleh perpustakaan.

Aspek tanggung jawab dan partisipasi mengacu pada meningkatnya tang- 
gung jawab dan partisipasi peserta didik terhadap proses pembelajaran yang ditempuhnya. Hal ini merupakan implikasi dari paradigma student-centered learning. Dari aspek motivasi, perpustakaan berupaya mendorong warga sekolah untuk membaca dan belajar. Motivasi yang diharapkan adalah motivasi intrinsik yang berasal dari dalam individu tersebut, bukan motivasi ekstrinsik karena faktor transaksional.

Beberapa contoh program yang dapat dilakukan oleh perpustakaan dengan mempertimbangkan keempat aspek tersebut misalnya penyediaan waktu yang lebih fleksibel kepada pemustaka, pelibatan seluruh komponen sekolah dalam kegiatan yang dilakukan perpustakaan, dan penggunaan koleksi pustaka secara efektif (Johnson, 1972, pp. 39-48). Mengenai penggunaan pustaka secara efektif, Johnson menambahkan bahwa tidak cukup hanya sekedar menyediakan koleksi bagi siswa, tetapi juga siswa harus dapat mempergunakan koleksi tersebut dan berinteraksi dengan cara bertanya dan berespon terhadap koleksi tersebut. Dengan kata lain, perpustakaan tidak cukup hanya menyediakan koleksi tetapi juga memikirkan bagaimana cara agar koleksi-koleksi tersebut termanfaatkan dengan baik oleh seluruh warga sekolah atau pemustaka.

Menurut Todd dan Kuhltau (2004) dalam Kaplan (2010), program perpustakaan dapat dikelompokkan menjadi tiga tipe, yaitu (1) informasional, (2) transformasional, dan (3) formasional. Kegiatan informasional mengarah pada infrastruktur dasar perpustakaan. Infrastruktur yang dimaksud adalah ketersediaan dan kemutakhiran koleksi pustaka cetak maupun elektronik dan teknologi yang memadai untuk mengakses koleksi pustaka elektronik. Kegiatan transformasional berhubungan dengan keterlibatan perpustakaan dalam pembelajaran, termasuk pengembangan keterampilan literasi informasi (baik di dalam maupun di luar kelas), literasi teknologi (penggunaan informasi elektronik yang sesuai), dan pembinaan minat baca baik untuk tujuan rekreasional maupun untuk menyelesaikan persoalan.
Kegiatan formasional berhubungan dengan penggunaan dan sintesis informasi oleh siswa sehingga mereka dapat mencapai standar yang diharapkan.

Berdasarkan latar belakang yang telah disampaikan, diketahui bahwa masalah yang muncul adalah peran kepala sekolah dan pustakawan dalam memberdayakan perpustakaan sekolah dasar sulit untuk dirumuskan. Selain itu, program pemberdayaan seperti apa yang dapat dilakukan oleh perpustakaan sekolah dasar pun belum diketahui secara luas. Oleh karena itu, penelitian ini bertujuan untuk mendeskripsikan peran kepala sekolah dan pustakawan dalam memberdayakan perpustakaan sekolah dasar, dan upaya pemberdayaan yang dapat dilakukan oleh perpustakaan sekolah dasar. Penelitian ini diharapkan dapat menjadi acuan kepada seluruh pihak yang memerlukan gambaran terperinci mengenai peran kepala sekolah dan pustakawan dalam pemberdayaan perpustakaan sekolah dasar serta upaya-upaya pemberdayaan yang dapat dilakukan oleh perpustakaan sekolah dasar

\section{Metode Penelitian}

Penelitian ini dilakukan dengan menggunakan pendekatan kualitatif karena dapat menggali lebih mendalam mengenai peran kepala sekolah dan peran pustakawan dalam memberdayakan perpustakaan di lokasi penelitian. Jenis penelitian yang digunakan adalah studi kasus karena karakteristiknya yang menekankan pada suatu inkuiri empiris yang menyelidiki fenomena di dalam konteks kehidupan nyata bilamana batas-batas antara fenomena dan konteks tidak tampak tegas (Yin, 2012, p. 18). Dalam penelitian ini, fenomena mengenai peran kepala sekolah dan pustakawan tidak dapat dipisahkan dari konteks perpustakaan sebenarnya. Peran kepala sekolah dan pustakawan hanya dapat diamati dan diobservasi apabila berada pada konteks lingkungan sebenarnya (Nasution, 1988, p. 26).

Mengingat kekhasan topik yang diangkat, penelitian dilakukan pada bulan 
April hingga Juli 2014 dengan mengambil lokasi di dua perpustakaan sekolah dasar yang ada di kota Yogyakarta, yaitu Perpustakaan "An-Nafid" SD Muhammadiyah Sapen sebagai dan Perpustakaan "Cempaka" SD Negeri Giwangan Yogyakarta sebagai. Kedua lokasi penelitian ini dipilih berdasarkan prestasi yang telah diraih oleh kedua perpustakaan sekolah dasar tersebut baik di tingkat daerah maupun nasional.

Berdasarkan tujuan penelitian yang hendak dicapai, maka subjek penelitian ini adalah Perpustakaan "An-Nafid" SD Muhammadiyah Sapen dan Perpustakaan "Cempaka" SD Negeri Giwangan Yogyakarta. Kepala sekolah dan pustakawan yang telah menjabat/bekerja selama lebih dari satu tahun menjadi key informan dalam penelitian ini. Selain kepala sekolah dan pustakawan, guru dan siswa juga terlibat sebagai informan dengan kriteria guru yang aktif memanfaatkan koleksi dan layanan perpustakaan, dan siswa kelas III-V yang dipilih secara acak.

Data yang digunakan dalam penelitian ini diperoleh dengan menggunakan beberapa teknik, yaitu observasi, wawancara, dan analisis dokumen. Dalam pelaksanaan penelitian, peneliti sebagai instrumen utama memanfaatkan instrumen pendamping seperti pedoman observasi, pedoman wawancara dan lembar analisis dokumen, serta didukung dengan peralatan rekam atau kamera.

Teknik wawancara diaplikasikan agar apa yang terkandung dalam pikiran dan hati informan, bagaimana pandangannya terkait dengan tema penelitian dapat digali secara mendalam melalui berbagai pendekatan, misalnya percakapan informal ataupun dengan memanfaatkan pedoman wawancara. Teknik observasi atau pengamatan secara langsung diaplikasikan guna mengamati aktivitas pemberdayaan perpustakaan sehari-hari dan tindakan atau kegiatan yang dilakukan oleh kepala sekolah dan pustakawan dalam upaya memberdayakan perpustakaan sekolah. Observasi yang dilakukan dalam penelitian ini mencakup observasi ruang dan kegiat- an yang berlangsung di dalam maupun luar ruang perpustakaan. Bentuk observasi partisipatif sedang diterapkan dalam teknik ini. Teknik ketiga, yaitu analisis dokumen melengkapi penggunaan dua metode lainnya. Dokumen yang digunakan berupa arsip perencanaan dan pelaksanaan program perpustakaan, gambar atau foto dan video mengenai kegiatan pemanfaatan perpustakaan, dan arsip evaluasi kegiatan perpustakaan.

Analisis data model interaktif menurut Miles dan Huberman (1994, p. 12) menjadi rujukan dalam menganalisis data yang diperoleh. Hasil pengumpulan data dari berbagai teknik akan mengalami reduksi yang mencakup kegiatan memilah-milahkannya ke dalam satuan konsep tertentu, kategori tertentu, atau tema tertentu. Hasil reduksi data kemudian disajikan ke dalam suatu bentuk tertentu sehingga terlihat pola yang lebih utuh dan lebih terorganisir agar memudahkan pemaparan dan penarikan kesimpulan.

Setiap data yang terkumpul dalam proses penelitian diberikan kode menurut teknik pengambilan data, kelompok informan dan waktu pengambilan. Selain itu, data-data penelitian berupa kegiatan juga dikelompokkan menjadi beberapa kategori terkait dengan topik penelitian

Keabsahan data pada penelitian ini mencakup kredibilitas, dependabilitas, dan konfirmabilitas menurut Nasution (1988, p. 105). Kredibilitas data yang diupayakan dalam penelitian ini dilakukan dengan memperpanjang masa observasi, triangulasi data baik metode maupun sumber, peer-debriefing, dan member-check. Aspek dependabilitas dan konfirmabilitas dipertahankan dengan adanya audit trail yang dapat terlacak.

\section{Hasil Penelitian dan Pembahasan}

\section{Profil Perpustakaan Sekolah Dasar}

Pada mulanya, kedua perpustakaan yang menjadi subjek penelitian kurang memperoleh perhatian dari sekolah; tempatnya tidak strategis, jauh dari pusat pembelajaran, kurang pencahayaan, koleksi 
tidak mutakhir, dan tidak tersedianya pengelola khusus/pustakawan penuh waktu. Hal ini menyebabkan perpustakaan belum dirasakan manfaatnya oleh warga sekolah.

Perpustakaan mulai berkembang dan dirasakan manfaatnya manakala kepala sekolah memutuskan untuk menempatkan pustakawan penuh waktu, baik dari kalangan guru ataupun dari ilmu perpustakaan murni. Komitmen kepala sekolah juga nampak manakala perpustakaan menempati ruangan yang lebih luas dan representatif sesuai dengan kebutuhan dan jumlah pemustaka yang dilayani.

Kehadiran seorang pustakawan penuh waktu yang profesional juga berpengaruh terhadap pemberdayaan perpustakaan sekolah dasar. Pustakawan yang mempunyai kemampuan dan keterampilan dalam bidang kepustakaan dan kepustakawanan mampu memberdayakan perpustakaan sekolah dimana ia melayani dengan cara mengembangkan koleksi pustaka yang beragam dan menyediakan lebih dari layanan dasar perpustakaan.

Selain layanan sirkulasi dan referensi, perpustakaan sekolah dasar yang diteliti juga telah menyelenggarakan berbagai program pemberdayaan, seperti pendidikan pemakai, wajib kunjung kelas, kelas alternatif, berbagai program pembinaan minat baca dan promosi, dan kerja sama dengan perpustakaan di luar sekolah. Pendidikan pemakai diberikan setiap awal tahun ajaran kepada siswa baru. Wajib kunjung kelas merupakan program rutin dan terjadwal yang memberikan kesempatan kepada seluruh kelas berkunjung ke perpustakaan. Perpustakaan juga menyediakan ruang yang representatif untuk melakukan proses pembelajaran. Inilah yang dinamakan dengan program kelas alternatif. Program pembinaan minat baca dan promosi dilakukan dengan menyelenggarakan berbagai lomba internal sekolah, ikut serta dalam lomba eksternal sekolah, story telling, movie box, dll.

Tujuan pemustaka memanfaatkan perpustakaan pun cukup beragam. Ada yang memanfaatkannya untuk tujuan rekreasional, untuk melakukan penelitian sederhana, untuk tujuan yang berhubungan dengan proses pembelajaran, untuk pengembangan profesionalisme pribadi, dan untuk mendukung program sekolah.

Para siswa secara rutin mengunjungi perpustakaan sebanyak dua sampai tiga kali dalam seminggu, dalam kunjungan mandiri baik individual maupun berkelompok. Akan tetapi keaktifan siswa ini tidak diiringi dengan keaktifan para guru. Berdasarkan data yang diperoleh, persentase guru yang aktif memanfaatkan perpustakaan dan layanannya berkisar antara $20-30 \%$. Hal ini menunjukkan bahwa kesadaran guru akan pentingnya perpustakaan bagi pembelajaran masih kurang sehingga akan menjadi tantangan bagi perpustakaan untuk menarik minat para guru.

Peran Kepala Sekolah dalam Pemberdayaan Perpustakaan Sekolah

Dalam organisasi sekolah, kepala sekolah memiliki wewenang untuk membawa seluruh komponen yang ada untuk bergerak menuju visi bersama sekolah yang telah disepakati. Salah satu komponen yang ada di sekolah adalah perpustakaan. Berdasarkan hasil penelitian diketahui bahwa tugas kepala sekolah terhadap perpustakaan meliputi lima aspek, yaitu (1) mengalokasikan sumber daya untuk perpustakaan, (2) mendorong program kerja sama perpustakaan, (3) melakukan monitoring dan evaluasi, (4) mendukung kolaborasi antara perpustakaan dengan guru, dan (5) mendorong keaktifan pemanfaatan perpustakaan sekolah.

Sumber daya yang dimaksud tidak hanya materiil tetapi juga sumber daya manusia. Kepala sekolah mengalokasikan anggaran sekolah untuk perpustakaan sebesar 2-5\%. Berdasarkan Pasal 23 UndangUndang No. 43 Tahun 2007 tentang Perpustakaan, sekolah mengalokasikan dana paling sedikit 5\% dari anggaran belanja operasional sekolah atau belanja barang di luar belanja pegawai dan belanja modal untuk pengembangan perpustakaan. Meskipun persentase anggaran yang dialokasikan belum mencapai standar yang ditetapkan, namun kepala sekolah telah berkomit- 
men untuk mendukung perpustakaan melalui penyediaan dana. Demikian pula dengan sumber daya manusia, kepala sekolah menempatkan pustakawan penuh waktu sesuai dengan kebutuhan perpustakaan.

Kepala sekolah mendorong kerja sama yang dilakukan oleh perpustakaan sekolah dengan perpustakaan di luar sekolah. Contohnya adalah kerja sama dengan perpustakaan daerah setempat. Bentuk kerja sama yang terjadi adalah dengan adanya perpustakaan keliling ke sekolah, peminjaman beberapa koleksi pustaka kepada perpustakaan selama jangka waktu tertentu, dan sosialisasi mengenai penyelenggaraan seminar atau diklat kepustakaan dan kepustakawanan.

Monitoring dan evaluasi juga dilakukan oleh kepala sekolah, meskipun pelaksanaannya masih bersifat spontanitas dan kekeluargaan. Hal ini dilakukan manakala kepala sekolah berkunjung ke perpustakaan dan bersikap selayaknya pemustaka lainnya. Guna meningkatkan pemberdayaan perpustakaan, kepala sekolah senantiasa mendorong terjadinya kolaborasi antara perpustakaan dengan guru untuk kepentingan proses pembelajaran. Mendorong keaktifan pemanfaatan perpustakaan sekolah juga menjadi tugas kepala sekolah. Dalam hal ini, kepala sekolah aktif menyampaikan himbauan/motivasi secara lisan, menjadi teladan dalam memanfaatkan perpustakaan, menggalakkan berbagai program perpustakaan.

Berbagai upaya terus dilakukan kepala sekolah guna memberdayakan perpustakaan, yaitu (1) mengintegrasikan perpustakaan ke dalam pembelajaran secara terjadwal, (2) meningkatkan kolaborasi antara pustakawan dengan guru, (3) memotivasi para guru, (4) meningkatkan peran guru koordinator, dan (5) melakukan supervisi secara kontinu.

Berdasarkan temuan tersebut, maka dapat dirumuskan bahwa kepala sekolah mempunyai tiga peran penting dalam pemberdayaan perpustakaan sekolah, yaitu sebagai (1) manajer, (2) pemimpin instruksional, dan (3) agen perubahan.

\section{Sebagai Manajer}

Kepala sekolah bertanggung jawab dalam mengelola sarana pendidikan, termasuk perpustakaan, agar dapat menciptakan suasana belajar yang konstruktif dan mendukung pembelajaran (Usman, 2006) dengan cara mengalokasikan berbagai sumber daya yang dimiliki untuk mendorong perpustakaan mencapai tujuan tersebut. Sumber daya yang dimiliki sekolah untuk perpustakaan meliputi sumber daya manusia, dana, dan materiil (koleksi pustaka).

Sebagai manajer yang efektif, kepala sekolah menekankan pada tiga faktor penting, yaitu (1) pencapaian tujuan dan penyelesaian tugas, (2) pemberian motivasi dan pengembangan setiap individu di dalam sekolah, dan (3) penggerakan dan pemeliharaan semangat kerja sama yang terjadi di sekolah (Dunham, 2005, p. 33). Untuk dapat melakukannya, kepala sekolah tidak cukup hanya menjadi manajer tetapi juga berperan sebagai pemimpin di sekolah. Seorang pemimpin akan mampu memotivasi, mengembangkan dan menggerakkan setiap individu di sekolah serta membangun semangat kerja sama di dalam sekolah.

Faktor pertama, kepala sekolah mempunyai wewenang untuk membawa perpustakaan menuju visi yang telah ditetapkan sehingga segala bentuk operasional, kegiatan dan kerja sama yang dilakukan oleh perpustakaan akan bermuara pada visi tersebut. Untuk mengetahui sejauh mana perpustakaan telah mencapai visi tersebut maka diperlukan supervisi dan evaluasi. Keduanya dilakukan secara kontinu agar perpustakaan dapat terus mengembangkan dirinya untuk mencapai visi bersama.

Faktor kedua, kepala sekolah menerapkan strategi kebijakan yang berbedabeda (Sergiovanni, 2001) untuk memberi motivasi dan mengembangkan setiap personil di sekolah. Misalnya, dengan penerapan aturan yang diberlakukan di sekolah, kepala sekolah sedang menerapkan strategi kebijakan yang berupa mandat. Dalam hal ini kepala sekolah sedang me- 
nempatkan diri sebagai manajer. Contoh lainnya, pemberian penghargaan kepada pemustaka teraktif dapat mengindikasikan bahwa kepala sekolah sedang menerapkan strategi kebijakan yang bersifat insentif dan menempatkan dirinya sebagai motivator.

Faktor ketiga, kepala sekolah dapat menggerakkan dan memelihara semangat kerja sama apabila seluruh individu yang terlibat di dalamnya menyadari kebutuhannya untuk meningkatkan kemampuan diri dan kemauan untuk berpartisipasi demi mencapai visi bersama. Kepala sekolah memberikan kesempatan kepada guru maupun tenaga kependidikan untuk meningkatkan kemampuannya sehingga dapat berpartisipasi dalam mencapai tujuan pendidikan di sekolah (Sergiovanni, 2001). Dengan demikian, kepala sekolah telah berperan tidak hanya sebagai pengembang, tetapi juga sebagai pembangun komunitas.

\section{Sebagai Pemimpin Instruksional}

Perubahan paradigma pendidikan menuntut perubahan metode pembelajaran. Di era dimana semua informasi bisa diakses dengan mudah dan berlimpah, metode pembelajaran konvensional yang indoktriner dan menghafal menjadi tidak relevan lagi untuk diterapkan. Siswa harus belajar mandiri dengan cara mencari sendiri informasi yang diperlukan dan kemudian mengolahnya. Keterampilan yang dibutuhkan siswa meliputi sejauh mana siswa mengetahui informasi apa yang dibutuhkannya, dimana mencarinya, bagaimana menemukannya, bagaimana memilahnya, bagaimana mengolah informasi tersebut untuk kemudian menyajikannya kepada orang lain.

Sebagai agen informasi terdepan yang dimiliki sekolah, pustakawan menjadi sumber terbaik yang dimiliki sekolah agar dapat menyesuaikan diri dengan perubahan masa kini. Oleh karena itu, pembelajaran yang integratif tidak hanya terjadi antarguru tetapi juga antara guru dengan pustakawan. Sebagai pemimpin instruksional, kepala sekolah mempunyai akses untuk meningkatkan kolaborasi pus- takawan dengan guru. Kolaborasi yang dimaksud tentunya berhubungan dengan kegiatan pembelajaran.

Kolaborasi antara guru dan pustakawan dapat meningkatkan pemberdayaan perpustakaan sebagai sarana pendukung pembelajaran. Untuk mewujudkan kolaborasi tersebut, kepala sekolah dapat membuka peluang kolaborasi dengan cara mengalokasikan waktu khusus dimana guru dan pustakawan dapat duduk bersama dan merencanakan kegiatan pembelajaran. Guru dianggap mempunyai keterampilan dalam mengajar dan mengetahui seluk beluk kurikulum yang digunakan, sedangkan pustakawan dianggap mempunyai keterampilan literasi informasi yang dibutuhkan dan mengetahui dengan pasti koleksi pustaka yang dimiliki dan dapat digunakan dalam pembelajaran serta bagaimana mempergunakannya.

\section{Sebagai Agen Perubahan}

Hasil penelitian mengungkapkan bahwa tidak mudah mengubah perilaku warga sekolah. Sebagai agen perubahan, kepala sekolah harus mampu mendeteksi manakala perubahan diperlukan, mengembangkan atau memilih inovasi yang diperlukan, dan mengarahkan warga sekolah menuju perubahan yang diharapkan (Gorton, 1976).

Kepala sekolah yang menyadari bahwa perpustakaan merupakan layanan khusus kepada warga sekolah dan sangat menunjang proses pembelajaran akan melakukan berbagai upaya yang diperlukan untuk mengaktifkan kegiatan perpustakaan dan memberdayakan pustakawannya. Hal ini terbukti dengan keberadaan salah satu perpustakaan yang cenderung lebih aktif dalam program pemberdayaan. Dengan keaktifan tersebut, warga sekolah pun kini lebih aktif memanfaatkan layanan perpustakaan.

Pemahaman kepala sekolah tentang arti penting perpustakaan bagi sekolah akan membawa dampak besar bagi perpustakaan. Arti penting perpustakaan bagi kepala sekolah akan nampak dalam setiap kebijakan yang dihasilkannya. Nilai, visi, 
dan komitmen kepala sekolah terhadap perpustakaan akan menjadi dasar dalam berpikir. Nilai-nilai tersebut kemudian disintesa dan direfleksikan sehingga kepala sekolah terus mengembangkan diri dan pemikirannya menghadapi situasi dan perubahan yang dihadapi oleh sekolah. Sintesa nilai-nilai tersebut akhirnya nampak dalam perilaku, keputusan, dan kebijakan kepala sekolah (Sergiovanni, 2001)

Peran Pustakawan dalam Pemberdayaan Perpustakaan Sekolah Dasar

Pustakawan merupakan ujung tombak pelayanan perpustakaan kepada warga sekolah. Sebuah perpustakaan tidak dapat berdampak positif dan berkelanjutan bagi proses pembelajaran tanpa adanya kerja sama antara kepala sekolah dan pustakawan. Pada umumnya, warga sekolah memahami bahwa pustakawan bertanggung jawab untuk mengelola perpustakaan beserta koleksi pustaka yang dimiliki sekaligus mengelola ruang perpustakaan itu sendiri sehingga siap dipergunakan oleh seluruh pemustaka. Berdasarkan hasil penelitian, ditemukan bahwa tugas-tugas pustakawan tidak hanya meliputi aspek manajerial, tetapi juga aspek-aspek yang lain seperti pengelolaan informasi, kependidikan, pengembangan profesi, sosial, dan kepribadian.

Aspek manajerial terwujud ke dalam beberapa tugas yang dikerjakan, yaitu: (a) melaksanakan kewajiban administratif, (b) mempersiapkan fasilitas perpustakaan, (c) menjaga kenyaman dan kebersihan perpustakaan, (d) merawat fasilitas perpustakaan, dan (e) mendistribusikan tugas dan tanggung jawab dengan rekan pustakawan

Dalam aspek pengelolaan informasi, pustakawan bertanggung jawab untuk mengembangkan dan mengorganisasikan koleksi, memberikan jasa dan layanan informasi, dan menerapkan teknologi informasi dan komunikasi yang diperlukan. Beberapa tugas yang menyertainya adalah: (a) mengembangkan dan mengorganisasikan koleksi pustaka, (b) mengimplementasikan teknologi informasi dan komunikasi dalam sistem perpustakaan, (c) bertang- gung jawab terhadap layanan sirkulasi, dan (d) memberikan layanan referensi dan penelusuran informasi

Aspek tugas selanjutnya adalah aspek kependidikan. Tugas pustakawan dalam aspek ini terwujud dalam: (a) bekerja sama dengan guru guna mendukung penyelenggaraan proses pembelajaran, (b) mempromosikan perpustakaan kepada pemustaka, dan (c) memberikan bimbingan literasi informasi

Pada aspek pengembangan profesi, Pustakawan bertanggung jawab untuk memberikan pelayanan prima kepada pemustakanya. Untuk itu, ia harus aktif mengembangkan profesionalismenya, baik secara mandiri maupun melalui pelatihan atau seminar yang diselenggarakan oleh institusi, perpustakaan daerah setempat, maupun organisasi-organisasi profesi. Pustakawan yang berkembang juga akan meningkatkan kebiasaan membaca untuk dirinya sendiri. Kebiasaan ini nampak pada seorang pustakawan yang aktif men-cari informasi terkini mengenai perkembangan peraturan pemerintah di bidang kepustakaan.

Dalam aspek sosial, pustakawan harus menjaga hubungan dan membangun komunikasi dengan rekan sekerja, pemustaka, kepala sekolah, dan seluruh warga sekolah. Kualitas komunikasi yang terbangun dengan rekan sekerja akan mendukung atau justru menghambat upaya pengembangan perpustakaan, baik dalam hal program, evaluasi maupun penegakan disiplin terhadap pemustaka. Membangun komunikasi antara pustakawan dengan guru juga akan mendukung koordinasi yang diperlukan agar perpustakaan dapat mendukung proses pembelajaran, maupun mendukung program sekolah. Komunikasi dengan siswa juga sangat diperlukan agar pustakawan dapat menjalin relasi yang bersahabat, memotivasi siswa sekaligus mendisiplin siswa ketika mereka berada di perpustakaan.

Pada aspek kepribadian, perilaku pustakawan menunjukkan bagaimana ia menjaga etos kerjanya. Kebiasaannya untuk datang tepat waktu dan tidak me- 
ninggalkan tugas tanpa alasan menjadi contoh indikator yang dapat diperhatikan untuk melihat aspek ini.

Berdasarkan keenam aspek tugas yang telah dikemukakan, maka dapat diketahui bahwa peran pustakawan dalam pemberdayaan perpustakaan sekolah dasar adalah sebagai (1) manajer perpustakaan, (2) ahli informasi dan penggiat literasi informasi, (3) kolaborator, dan (4) pelaku instruksional.

\section{Manajer Perpustakaan}

Sebagai manajer dari perpustakaan, pustakawan mempunyai kewajiban untuk mengelola perpustakaan agar siap digunakan oleh pemustaka. Dengan demikian, pustakawan bertanggung jawab untuk mempersiapkan perpustakaan dari aspek administratif hingga teknis dan terus berupaya untuk meningkatkan pemberdayaan perpustakaan di kalangan warga sekolah. Hal inilah yang nampak dalam kegiatan yang dilakukan oleh pustakawan seharihari berdasarkan aspek manajerial dan integritas yang ditunjukkan dalam aspek kepribadian.

\section{Ahli Informasi dan Penggiat Literasi Informasi}

Sebagai ahli informasi dan penggiat literasi informasi, pustakawan tidak hanya bertanggung jawab untuk menyediakan dan mengelola informasi tetapi juga menjadi teladan dalam pemerolehan, pengolahan, dan penggunaan informasi. Agar tanggung jawab tersebut dapat terimplementasi dengan baik sesuai dengan kebutuhan di dunia informasi saat ini, maka pustakawan harus memahami tugasnya dan mempersiapkan dirinya sebagaimana kegiatan yang nampak dilakukan pustakawan dalam aspek pengelolaan informasi dan aspek pengembangan profesi.

\section{Kolaborator}

Sebagai kolaborator, pustakawan proaktif berkolaborasi dengan para guru guna menciptakan pengalaman belajar yang beragam dan berkualitas bagi siswa. Kolaborasi hanya dapat terjadi manakala terjadi proses interaksi dan pertukaran pengetahuan dan keterampilan yang saling melengkapi. Berdasarkan hasil penelitian, kolaborasi yang terjadi justru tidak mengarah kepada peningkatan kualitas pengalaman belajar dan kurang memberikan peluang kepada pustakawan untuk terlibat dalam perencanaan maupun pelaksanaan pembelajaran. Tugas yang berhubungan dengan aspek kependidikan mampu membantu pustakawan menjalankan peran ini disertai dengan kemampuan dari aspek sosial guna membangun komunikasi yang lebih baik dengan para guru, siswa, termasuk kepala sekolah.

\section{Pelaku Instruksional}

Peran pustakawan sebagai pelaku instruksional bukan berarti pustakawan menggantikan peran guru dalam pembelajaran. Sebagai pelaku instruksional, pustakawan mempunyai tugas yang berbeda dengan guru. Pustakawan dapat mengimplementasikan peran tersebut dengan baik apabila sudah terjadi kolaborasi yang solid dengan para guru. Sebagaimana tercermin dalam aspek kependidikan, pustakawan telah mengambil bagian dalam penyelenggaraan pembelajaran, yaitu dengan menyediakan alat-alat pembelajaran yang dibutuhkan oleh para guru. Disamping itu, peran ini berkaitan erat dengan peran pustakawan sebagai ahli informasi dan penggiat literasi informasi. Sudah menjadi tugas pustakawan untuk menyebarluaskan kemampuan dan keterampilannya dalam mengorganisasikan informasi kepada siswa maupun guru.

Pemberdayaan Perpustakaan Sekolah Dasar

Berbicara mengenai pemberdayaan perpustakaan, perlu disadari bahwa perpustakaan merupakan sumber belajar yang didesain untuk kepentingan peningkatan pembelajaran di sekolah. Oleh karena itu, sebagai bagian integral dari komunitas sekolah, perpustakaan dan segala kegiatannya harus dipandang dalam kerangka pembelajaran (Prostano dan Prostano, 1977; Lance, 2002).

Seluruh layanan dan program perpustakaan yang telah dipaparkan dapat 
digolongkan ke dalam beberapa kelompok. Berdasarkan sifatnya, kegiatan di perpustakaan digolongkan ke dalam tiga kelompok kegiatan yaitu informasional, transformasional, dan formasional (Kaplan, 2010).

Kegiatan yang bersifat informasional berarti seluruh kegiatan perpustakaan yang mengacu pada penyediaan infrastruktur dasar dan mengarah pada ketersediaan serta kemutakhiran sumber informasi dan teknologi untuk mengakses pustaka elektronik. Berdasarkan hasil di lapangan terbukti bahwa koleksi pustaka yang beragam dan tersedia dalam jumlah yang mencukupi mampu menjadi nilai tambah bagi perpustakaan sekolah. Perpustakaan pun secara kontinu menambah jumlah dan memperbarui koleksinya, baik fiksi maupun nonfiksi, agar sesuai dengan kebutuhan dan minat pemustaka. Koleksi pustaka yang dimaksud tidak hanya dalam bentuk cetak tetapi juga elektronik.

Kegiatan yang bersifat transformasional berarti seluruh kegiatan perpustakaan yang berhubungan dengan keterlibatan perpustakaan dalam pembelajaran. Misalnya, pembinaan minat baca untuk tujuan rekreasional maupun penelitian sederhana dan pengembangan keterampilan literasi informasi dan teknologi. Dalam implementasi sehari-hari, perpustakaan yang diteliti telah menerapkan program peningkatan minat baca melalui kerja sama dengan perpustakaan umum dan melalui penyelenggaraan berbagai macam lomba yang berhubungan dengan kepustakaan baik internal maupun eksternal sekolah.

Meski demikian, kegiatan transformasional yang belum digarap dengan baik oleh perpustakaan sekolah dasar adalah pengembangan keterampilan literasi informasi dan teknologi. Keberadaan teknologi tak terlelakkan dari kehidupan sekolah. Teknologi yang dimaksud tidak terbatas pada ketersediaan alat-alat berteknologi canggih untuk mendukung pembelajaran, tetapi bagaimana warga sekolah mampu menggunakan teknologi untuk mendukung pembelajaran secara mandiri maupun bersama-sama. Di era membanjirnya informasi, segala sesuatu bisa diperoleh guru dan siswa dengan mudah dan cepat. Dibutuhkan keterampilan bagi mereka dalam mencari, menemukan, memverifikasi dan mengekstrak informasi yang diperlukan. Untuk itulah keterampilan literasi informasi menjadi salah satu keterampilan yang dibutuhkan.

Kegiatan yang bersifat formasional merupakan kegiatan yang berhubungan dengan penggunaan dan sintesis informasi oleh siswa untuk mencapai standar kurikulum yang telah ditetapkan. Kegiatan yang bersifat formasional bisa jadi masih asing bagi perpustakaan dan pemustaka sekolah dasar. Akan tetapi kebutuhan akan kegiatan yang bersifat formasional tidak terbantahkan lagi.

Kegiatan ini berkaitan erat dengan pengembangan keterampilan literasi informasi. Jika pemustaka sudah terampil mencari, menemukan, memverifikasi dan mengekstrak informasi yang diperlukannya, maka tahap selanjutnya adalah melakukan sintesa terhadap temuannya tersebut sehingga menjadi sebuah pemahaman baru bagi pemustaka tersebut kemudian menyampaikannya kepada orang lain sehingga dapat dipergunakan (Simpson, 1998).

Dengan mempertimbangkan hasil penelitian yang diperoleh serta kajian yang dilakukan, maka pemberdayaan perpustakaan sekolah dasar diarahkan pada tiga hal, yaitu (a) peningkatan kolaborasi antara pustakawan dengan guru, (b) pengembangan keterampilan literasi informasi yang terintegrasi ke dalam pembelajaran, dan (c) peningkatan partisipasi warga sekolah terhadap pengembangan koleksi pustaka.

Peningkatan Kolaborasi antara Pustakawan dengan Guru

Pemberdayaan perpustakaan harus diarahkan demi mendukung pembelajaran secara integratif. Hal inilah yang perlu disadari oleh seluruh warga sekolah. Perpustakaan memiliki berbagai macam dan bentuk koleksi yang dapat dijadikan sebagai sumber belajar selain buku teks yang sudah digunakan. Guru memiliki pengetahuan dan keterampilan yang cukup 
mengenai kurikulum dan proses pembelajaran yang akan diterapkan. Keduanya dapat bersinergi dan saling melengkapi apabila memiliki kesempatan untuk berkolaborasi dalam menyusun rencana pembelajaran dan menyediakan lingkungan pembelajaran yang konstruktif dengan mempertimbangkan keberagaman siswa.

Kolaborasi dapat dimaknai sebagai proses interaksi antara pihak-pihak, dalam hal ini adalah pustakawan dan guru, yang memiliki keterampilan khusus dan saling melengkapi sehingga mendorong terjadinya pertukaran pengetahuan dan penghargaan atas berbagai perspektif demi menciptakan atau menyediakan sebuah pemahaman atau pengalaman belajar yang baru bagi siswa (Begley, 2003; Picciano, 2011). Berdasarkan hasil penelitian, diketahui bahwa bentuk kegiatan kolaborasi antara pustakawan dan guru yang telah berjalan selama ini adalah mengumpulkan dan menyediakan koleksi yang dibutuhkan untuk pembelajaran. Bentuk kegiatan ini akan terjadi apabila ada permintaan dari guru yang bersangkutan.

Kolaborasi dapat terwujud melalui beberapa aspek kegiatan (Prostano dan Prostano, 1977; Lance, 2002), yaitu: (1) mengidentifikasi, mengumpulkan, dan menyediakan media, teknologi, dan informasi yang diperlukan guru dalam pembelajaran, (2) melakukan perencanaan pembelajaran bersama dengan guru, termasuk merencanakan metode dan kegiatan belajar yang sesuai, (3) menyediakan kegiatan in-service bagi guru. Apabila mengacu pada hal ini, maka kolaborasi hendaknya dimulai sejak perencanaan pembelajaran. Dengan kata lain, pustakawan sebaiknya dilibatkan ketika para guru membuat perencanaan sehingga dapat mengidentifikasi kebutuhan sumber referensi pembelajaran dan merekomendasikan cara penggunaannya.

Perluasan kesempatan kolaborasi perpustakaan ke dalam proses pembelajaran perlu difasilitasi oleh sekolah. Implikasi yang muncul dengan adanya peningkatan kolaborasi ini adalah perlunya meninjau kembali struktur organisasi perpustakaan dengan menyediakan akses koordinasi an- tara perpustakaan dengan bagian kurikulum atau pengajaran. Dengan adanya garis koordinasi ini, pustakawan memperoleh akses dan dukungan legitimasi untuk berkolaborasi dengan para guru untuk bersama-sama merencanakan pengalaman belajar bagi siswa.

Pengembangan Keterampilan Literasi Informasi yang Terintegrasi ke dalam Pembelajaran

Literasi informasi merupakan kemampuan untuk menyadari kebutuhan informasi dan kapan informasi diperlukan, mengidentifikasi dan menemukan lokasi informasi yang diperlukan, mengevaluasi informasi secara kritis, mengorganisasikan dan mengintegrasikan informasi ke dalam pengetahuan yang sudah ada, memanfaatkan serta mengkomunikasikannya secara efektif, legal, dan etis. Setiap warga sekolah, tanpa terkecuali, perlu mempelajari, menangani, dan mempergunakan informasi yang berlimpah dan mampu menilai tingkat kepercayaan dari informasi tersebut. Oleh karena itu, pengembangan keterampilan ini dapat menjadi salah satu kunci untuk memberdayakan perpustakaan sekolah dasar sehingga benar-benar mendukung dan terintegrasi ke dalam pembelajaran.

Untuk dapat memulai program pengembangan keterampilan literasi informasi, perpustakaan dapat memanfaatkan program wajib kunjung yang sudah terjadwal. Adanya dua orang pustakawan di perpustakan menjadi potensi yang harus dimanfaatkan. Dalam kegiatan wajib kunjung tersebut, pustakawan dapat mulai memperkenalkan dan mengembangkan keterampilan literasi informasi mengingat tingkat kepentingan dan belum tergarapnya program pemberdayaan ini di lingkungan sekolah dasar. Namun, sekali lagi, hal ini dapat terwujud apabila terjadi kolaborasi antara pustakawan, guru, dan kepala sekolah.

Peningkatan Partisipasi Warga Sekolah dalam Pengembangan Koleksi Pustaka

Perpustakaan akan mampu menambah dan mengembangkan koleksi pustaka 
yang sesuai dengan kebutuhan dan minat pemustaka apabila pemustaka terlibat aktif dalam merekomendasikan koleksi yang dibutuhkan atau diinginkannya. Hal ini terbukti manakala siswa diberikan kesempatan untuk memilih koleksi yang mereka inginkan, mereka akan lebih aktif membaca dan meminjam koleksi tersebut. Dengan memberikan kesempatan siswa berkontribusi, keterampilan membaca siswa akan meningkat dan antusiasme membaca pun bertambah karena suara mereka didengar dan dihargai oleh pustakawan (Smith, 2012). Peningkatan partisipasi ini juga memberikan kesempatan yang sama kepada semua guru. Sebagai salah satu sumber terpercaya dalam pembelajaran, guru mengetahui dengan benar koleksi apa saja yang dibutuhkannya untuk pembelajaran maupun untuk meningkatkan kualitas pembelajaran.

Terbukanya kesempatan yang sama bagi siswa dan guru untuk berkontribusi dalam pemilihan dan pengembangan koleksi pustaka tidak memandang kedekatan pustakawan dengan siswa atau guru tertentu. Seluruh warga sekolah mempunyai akses yang sama untuk berperan serta. Untuk itu, perpustakaan perlu membuka akses yang seluas-luasnya bagi seluruh warga sekolah agar dapat berkontribusi dalam pemberdayaan ini.

Apabila partisipasi warga sekolah meningkat maka layanan sirkulasi akan semakin aktif, motivasi membaca meningkat, dan rasa memiliki terhadap perpustakaan semakin terbentuk. Pengembangan rasa memiliki terhadap perpustakaan akan mendorong tanggung jawab seluruh pemustaka untuk menjaga dan merawat perpustakaan, dan saling menghormati antarpemustaka.

\section{Simpulan dan Saran}

Simpulan

Kepala sekolah berperan sebagai: (1) manajer, (2) pemimpin instruksional, dan (3) agen perubahan. Peran pustakawan adalah sebagai (1) manajer perpustakaan, (2) ahli informasi dan penggiat literasi informasi, (3) pelaku instruksional, dan (4) kolaborator. Upaya pemberdayaan perpustakaan sekolah dasar diarahkan kepada tiga aspek, yaitu (1) peningkatan kolaborasi antara pustakawan dengan guru, (2) pengembangan keterampilan literasi informasi yang terintegrasi ke dalam pembelajaran, dan (3) peningkatan partisipasi warga sekolah terhadap pengembangan koleksi pustaka.

Saran

Untuk meningkatkan manfaat perpustakaan sekolah dasar, beberapa saran yang dapat dilakukan adalah: (a) menyediakan jalur koordinasi antara perpustakaan dengan bagian akademik/kurikulum di dalam struktur organisasi untuk memberikan akses kolaborasi yang lebih luas, (b) kepala sekolah dapat mengalokasikan waktu rutin secara kontinu untuk perencanaan kolaboratif, (c) pustakawan memberikan akses kepada warga sekolah untuk berpartisipasi mengembangkan koleksi pustaka sesuai dengan format yang disepakati, dan (d) pustakawan sebaiknya memanfaatkan jadwal wajib kunjung kelas untuk memperkenalkan dan mengembangkan keterampilan literasi informasi kepada siswa.

\section{Daftar Pustaka}

Barnawi \& Arifin, M. (2012). Manajemen sarana dan prasarana sekolah. Yogyakarta: Ar-Ruzz Media.

Begley, P.T \& O. Johansson. (2003). The Ethical Dimensions of School Leadership. New York: Kluwer Academic Publisher.

Cunningham, W.G., \& Cordeiro, P.A. (2009). Educational leadership: a bridge to improved practice. Boston: Pearson Education.

Darmono. (2007). Pengembangan perpustakaan sekolah sebagai sumber belajar. Jurnal Perpustakaan Sekolah, 1 (1), 1-10. 
Dunham, J. (2005). Developing effective school management. London: Taylor \& Francis.

Edwards, Brian \& Fisher, Biddy. (2002). Library and learning resouce centres. Oxford: Architectural Press.

Gorton, R.A. (1976). School administration: challenge and opportunity for leadership. Iowa: Wm.C.Brown.

Kaplan, A.G. (2010). School library impact studies and school library media programs in the United States. School Libraries Worldwide, 16 (2), 5563.

Kemdiknas. (2008). Peraturan Menteri Pendidikan Nasional Nomor 25, Tahun 2008, tentang Standar Tenaga Perpustakaan Sekolah/Madrasah.

Kowalski, T.J. (2010). The school principal: Visionary leadership and competent management. New York: Routledge.

Lance, K.C. (2002). What research tells us about the importance of school libraries. Knowledge Quest, 9 (2), 17 22.

Miles, M. B., \& Huberman, A. M. (1994). An Expanded sourcebook qualitative data analysis. California: SAGE Publications.

Moore, D.P. (1999). Facilities and learning styles. School Planning and Management, 38 (4), 22.

Morris, B.J. (2010). Administering the school library media center. Santa Barbara: Libraries Unlimited.
Nasution, S. (1988). Metode penelitian naturalistik-kualitatif. Bandung: Tarsito.

Perpustakaan Nasional Republik Indonesia. (2007). Undang-undang RI nomor 43, tahun 2007, tentang Perpustakaan.

Picciano, A.G. (2011). Educational leadership and planning for technology. New Jersey: Pearson Education.

Prostano, E.T \& Prostano, J.S. (1977). The School library media center. Colorado: Libraries Unlimited.

Sergiovanni, T.J. (2001). Leadership: what's in it for schools?. London: Routledge.

Simpson, C. (1998). The School librarian's role in the electronic age. Emergency Librarian, 25 (5), 38-39.

Smith, N.L. (2012, Mei). Showing you care: suggestions for school library relationship. Knowledge Quest, 40 (6), 18-21.

Tilaar, H.A.R. (1998). Manajemen Pendidikan Nasional: Kajian Pendidikan Masa Depan. Bandung: Rosdakarya.

Usman, H. (2006). Manajemen: Teori, praktik, dan riset pendidikan. Jakarta: Bumi Aksara.

Whitehead, B.M., Boschee, F., \& Decker, R.H. (2013). The principal: Leadership for a global society. California: SAGE Publications.

Yin, R.K. (2012). Studi kasus: desain dan metode. (Terjemahan M. Djauzi Mudzakir). Jakarta: Rajawali Press. 